\title{
Field Resistance of Coat Protein Transgenic Papaya to Papaya ringspot virus in Jamaica
}

Paula Tennant, Biotechnology Center and Department of Life Sciences, University of the West Indies, Mona, Jamaica; M. H. Ahmad, Biotechnology Center, University of the West Indies, Mona, Jamaica; and D. Gonsalves, Department of Plant Pathology, Cornell University, Geneva, NY 14456

\begin{abstract}
Tennant, P., Ahmad, M. H., and Gonsalves, D. 2005. Field resistance of coat protein transgenic papaya to Papaya ringspot virus in Jamaica. Plant Dis. 89:841-847.

Transgenic papayas (Carica papaya) containing translatable coat protein $\left(\mathrm{CP}_{\mathrm{T}}\right)$ or nontranslatable coat protein $\left(\mathrm{CP}_{\mathrm{NT}}\right)$ gene constructs were evaluated over two generations for field resistance to Papaya ringspot virus in a commercial papaya growing area in Jamaica. Reactions of $\mathrm{R}_{0} \mathrm{CP}_{\mathrm{T}}$ transgenic lines included no symptoms and mild or severe leaf and fruit symptoms. All three reactions were observed in one line and among different lines. Trees of most $\mathrm{CP}_{\mathrm{NT}}$ lines exhibited severe symptoms of infection, and some also showed mild symptoms. $\mathrm{R}_{1}$ offspring showed reactions previously observed with parental $\mathrm{R}_{0}$ trees; however, reactions not previously observed or a lower incidence of the reaction were also obtained. The transgenic lines appear to possess virus disease resistance that can be manipulated in subsequent generations for the development of a product with acceptable commercial performance.
\end{abstract}

Additional keywords: horticultural evaluation, transgenic resistance

In 1949, Jensen reported that the first papaya disease attributed to a virus was described in the Caribbean (14). According to Jensen, the virus, presumably Papaya ringspot virus (PRSV), was recorded by Smith in 1929 and was considered the primary reason for no large-scale cultivation of papaya (Carica papaya L.) in Jamaica. However, in the mid-1980s, papaya (also locally known as pawpaw) was promoted in the agricultural sector as a viable alternative to traditional crops. Subsequently, organized commercial orchards were established across the island with the Sunrise solo cultivar (12). Over 240 ha of papaya were put into production by 1994 (24), and Jamaica, by then, was recognized as a leading exporter of papaya in the Caribbean. With this rapid expansion in the cultivation of papaya, PRSV gained prominence and once again was recognized as a potential problem to the production of the fruit crop in Jamaica.

PRSV, a member of the genus Potyvirus in the Potyviridae plant virus family, consists of flexuous particles with a monopartite RNA genome $(5,20,27)$. In papaya,

Corresponding author: Paula Tennant E-mail: paula.tennant@uwimona.edu.jm

Current address of D. Gonsalves: Pacific Basin Agricultural Research Center, ARS-USDA, 99 Aupuni St., Ste. 204, Hilo, Hawaii 96720.

Accepted for publication 4 April 2005.

DOI: 10.1094/PD-89-0841

(C) 2005 The American Phytopathological Society
PRSV induces mosaic, leaf discolorations, severe leaf deformations, ringspot blemishes on fruits, and overall stunting of the plant (10). Over the past two decades, various gene transfer methodologies have been utilized in the improvement of papaya germ plasm for resistance or tolerance to PRSV. Both conventional methods involving the introgression of genes from relatives in Caricaceae (18) or genetic modification of commercial varieties with viral transgenes have been investigated (11). The latter approach of genetic engineering has proven very successful using the coat protein $(\mathrm{CP})$ gene of the virus and has led to the development of PRSVresistant varieties in various regions $(1,3,7,9,16,26)$. Field evaluations in Hawaii, Florida, and Taiwan have reported on resistance phenotypes ranging from moderate protection $(3,26)$ to complete protection against systemic infections $(8,17)$. Resistance conferred by $\mathrm{CP}$ transgenic papaya also has been described as sequence specific and associated with suppressed accumulation of $\mathrm{CP}$ transgene mRNA and protein expression (23). Most importantly, loss of vigor or horticultural characteristics of the transgenic cultivar has not been documented $(8,11,17)$. Field tests of transgenic papaya in Hawaii report on percent soluble solids above the minimum required for commercial fruit and yields of almost three times those of industry averages $(8,19)$.

In Jamaica, transgenic papayas were developed through a technology transfer program with Cornell University and the Jamaica Agricultural Development Foun- dation. Papaya embryos were transformed with translatable $\left(\mathrm{CP}_{\mathrm{T}}\right)$ and nontranslatable $\left(\mathrm{CP}_{\mathrm{NT}}\right)$ versions of the $\mathrm{CP}$ gene of a virus isolate from one region of the island (along with nptII and uidA genes) via microprojectile bombardment $(2,22)$. Varying levels of CP transcript and protein were detected in northern analysis and enzyme-linked immunosorbent assay (ELISA) with $\mathrm{CP}_{\mathrm{T}}$ lines, and as expected, $\mathrm{CP}$ expression was not detected in $\mathrm{CP}_{\mathrm{NT}}$ lines (22). All $\mathrm{R}_{0}$ plants, while maintained under greenhouse conditions, tested positive for the nptII gene in polymerase chain reaction (PCR) and expression protein in ELISA (22). Initial greenhouse evaluation identified lines resistant to mechanical inoculations with homologous and heterologous isolates of the virus (22). In this study, two generations $\left(R_{0}\right.$ and $\left.R_{1}\right)$ of transgenic lines were field-tested in one of the traditional papaya producing regions of the island in order to assess resistance under natural virus pressure as well as horticultural performance of the lines.

\section{MATERIALS AND METHODS}

Transgenic plant materials. Papaya tissue culture materials (Sunrise solo) were transformed via microprojectile bombardment (2) with the CP gene of a PRSV isolate collected from Jamaica (Caymanas), along with the neomycin phosphotransferase type II (nptII) and $\beta$-glucuronidase (uidA) genes (22). Two versions of the $\mathrm{CP}$ gene were used; a translatable version (engineered $15 \mathrm{nts}$ after the CP gene start site described by Quemada et al. (21) and a nontranslatable version (containing an engineered stop codon 12 nts following the CP start site defined by Yeh et al. (25). Tissue culture, transformation, and hardening of plantlets in the greenhouse were done at Cornell University. Vegetative clones from in vitro micropropagation and rooted cuttings (generated from shoot tips and side shoots after plantlets were transferred to the greenhouse) were shipped to Jamaica, and then established in an experimental field plot under a permit from the National Biosafety Committee (Jamaica).

Field plots. Upon transfer to Jamaica, primary transformants $\left(\mathrm{R}_{0}\right)$ were acclimatized for 2 to 3 weeks under shade house conditions and subsequently transferred to a 0.2-ha field plot (1998) on a commercial farm, Brampton Farm, St. Catherine, 
which is situated along the southeastern coast of the island. This is the same region from which the progenitor virus that was used for transformation experiments was obtained. The plot was divided into 13 rows with 3-m spacing between rows and $1.5 \mathrm{~m}$ between each plant within a row. A guard row of nontransformed Sunrise solo papaya plants was established in the two outer rows and as the first plant of each row. Given the numbers of plants available for each transgenic line, 116 transgenic and 33 nontransformed plants were randomly established in the inner 11 rows (12 to $21 \mathrm{CP}_{\mathrm{T}}$ or $\mathrm{CP}_{\mathrm{NT}}$ transgenic plants and 2 to 5 nontransformed plants per row). On transfer to the plot, leaf extracts of the transgenic lines were tested by ELISA. Plants were maintained by standard agricultural practices generally used with papaya for the control of fungi and mites (Jamaica Papaya Growers Association, personal communication); apart from two applications of insecticides in June and November of 1999 for the control of leaf hoppers and thrips, no aphid control measures were implemented.

Given the stipulations of the permit obtained from the National Biosafety Committee (NBC) for field testing, there was no mechanical inoculation of virus, and papaya fields in the nearby regions served as the primary virus source; natural spread of PRSV in the plot was achieved by indigenous aphid-vector populations. Within the first 5 to 6 months, young fully expanded leaves of the canopy were scored in the following categories once per week: $\mathrm{S}_{\mathrm{S}}=$ severe mosaic on foliage, reduction or deformation of leaves, and/or fruits covered with ringspot blemishes; $\mathrm{S}_{\mathrm{A}}=$ mild or attenuated mosaic on foliage; and NS $=$ no symptom expression on foliage or fruits. Plants that were severely infected with the virus were not removed from the plot and provided high disease pressure; only plants suffering from root rot or bunchy top disease were removed ( 8 and 21 plants in 1999 and 2000, respectively). Assessment of additional categories of symptom expression continued for 15 months (1998 to 2000) and included: $S_{D}=$ severe symptoms on foliage or fruits after 14 to 21 months, $\mathrm{S}_{\mathrm{DA}}=$ mild or attenuated mosaic on foliage after 14 to 21 months, and $S_{R}=$ recovery from severe symptoms, as well as the previous $\mathrm{NS}=$ no symptom expression on foliage or fruits. Visual ratings were confirmed by assaying leaf samples by $\mathrm{CP}$ ELISA at 6, 15, and 21 months.

Seeds obtained from $\mathrm{R}_{0}$ transgenic lines (self pollinated bisexual trees, manually or open pollinated pistillate trees) were used to set up another field plot (1999 to 2001) on the same farm. Plant spacing, border plants, agricultural practices, and disease assessment were the same as described with the $\mathrm{R}_{0}$ test plot. Selection on the basis of resistance to PRSV or horticultural evaluation was not conducted, and proge- nies of all the lines were established in the second plot. Seedlings were first assayed by NPTII-ELISA to identify nontransgenic segregants. NPTII-positive (89 plants), NPTII-negative (88 plants), and nontransformed Sunrise solo (15 plants) papayas were established in two randomized complete blocks in a 0.4-ha plot.

Evaluation of tree and fruit characteristics. The desired tree and fruit characteristics of the export market as defined by the Jamaica Papaya Growers Association include trees that start bearing fruit at a low height of approximately 1 to $1.25 \mathrm{~m}$ from ground level and produce pearshaped fruits (shape indices of 0.64 to 0.77) with red flesh, total soluble solids (TSS) of at least $12 \%$, and weights between 274 to $744 \mathrm{~g}$ for the U.S. and Canadian markets or 225 to $535 \mathrm{~g}$ for the European market. The major requirement for the local market is large, fleshy fruits. These tree and fruit characteristics were therefore observed.

At the start of flowering ( 9 to 12 months postplanting), the sex of the trees was surveyed. Tree vigor, measured as trunk girth at $10 \mathrm{~cm}$ above ground level, was evaluated at 6 months postplanting. Fruit weights $(\mathrm{kg})$ and shape index (length to width ratio in $\mathrm{cm}$ ) were noted at commercial maturity (defined as the first indication of yellowing). Other attributes of fruits such as flesh color (visual rating of fruit pulp) and TSS were determined at eating maturity (i.e., when fruits were ripe). For the latter tests, pulp samples (three per fruit) were pressed through cheesecloth and the refractive index of expressed juice measured with a hand-held refractometer (Bellingham and Stanley Ltd., Lawrenceville, GA). Assays were conducted to determine the presence or activity of expression products of the transgenes (CP, NPTII, and GUS) in the fruit pulp using ELISA and histochemical assays. Positive controls provided by the manufacturers of the ELISA kits were included in the former tests and $\beta$-glucuronidase enzyme from Sigma in the latter assays.

Assays for the detection or activity of transgene expression proteins. Double antibody sandwich (DAS)-ELISA was conducted using polyclonal antisera against PRSV CP (Agdia, Elkhart, IN) and NPTII protein (formerly 5 Prime 3 Prime Inc., Boulder, CO). Conditions described by the manufacturers were followed in both assays apart from a few changes that are described herein. In ELISA for the detection of CP (CP-ELISA), coating polyclonal antibodies to PRSV were added at a dilution of 1:2,000 to microtiter plates and incubated at $4^{\circ} \mathrm{C}$ overnight. Plates were subsequently washed with PBST (10 $\mathrm{mM}$ sodium phosphate, $150 \mathrm{mM}$ sodium chloride, $0.05 \%$ Tween 20 ) and incubated at $4{ }^{\circ} \mathrm{C}$ overnight with homogenized sample extract of transgenic ( 2 to $7 \mathrm{mg}$ leaf or fruit), healthy, and PRSV-infected non- transformed Sunrise solo papaya. All plant extracts were prepared at a 1:50 dilution in extraction buffer $(0.25 \mathrm{M}$ potassium phosphate, $0.1 \mathrm{M}$ ethylene diaminetetraacetic acid, disodium salt, $\mathrm{pH}$ 7.5). After washing with PBST, anti-PRSV antibodies conjugated to alkaline phosphatase were transferred at a dilution of 1:2,000 and plates incubated for $5 \mathrm{~h}$ at $30^{\circ} \mathrm{C}$. Absorbance readings were then taken at $405 \mathrm{~nm}$ (BioTek Instruments, Highland Park, VT) 60 min after the addition of substrate (1 $\mathrm{mg} / \mathrm{ml} p$-nitrophenyl phosphate in $10 \%$ diethanolamine, $\mathrm{pH}$ 9.8).

Sample preparations were conducted as with the CP-ELISA in assays for the detection of NPTII protein (NPTII-ELISA). Controls included nontransformed papaya seedlings and a positive from the kit. Dilutions of 1:2,500 for coating, biotin, and streptavidin conjugated antibodies were used and incubated overnight at $4{ }^{\circ} \mathrm{C}$ with coating antibodies and at room temperature for 3 and $5 \mathrm{~h}$ with biotin and streptavidin conjugated antibodies, respectively. Absorbance readings at $405 \mathrm{~nm}$ were recorded $20 \mathrm{~min}$ after the addition of substrate $(1 \mathrm{mg} / \mathrm{ml} p$-nitrophenyl phosphate in $10 \%$ diethanolamine, $\mathrm{pH} 9.8$ ). A reaction with an average absorbance reading three times that of the negative control readings (nontransformed papaya) was regarded as positive in both assays.

Activity of the uidA expression protein (GUS) was determined in histochemical staining with samples (ca. 2 to $7 \mathrm{mg}$ fruit). Samples were incubated with $100 \mu \mathrm{I}$ XGluc $(0.96 \mathrm{mM}$ 5-bromo-4-chloro-3indoyl- $\beta$-glucoronide in $200 \mathrm{mM}$ sodium phosphate buffer) for $12 \mathrm{~h}$ at $37^{\circ} \mathrm{C}$. A blue color change (blue dots scattered across the tissue or a uniform blue color change in the tissue) was regarded as a positive reaction. Negative and positive controls included leaf samples from nontransformed papaya and purified $\beta$ glucuronidase enzyme (1U, EC 3.2.1.3 SIGMA G8271), respectively.

\section{RESULTS}

Within 9 months, $22 \%$ of the nontransformed papaya trees in the guard row and $48 \%$ in the plot of the first trial developed severe mosaic and some fruit blemishes typical of PRSV infections. At 17 months, all nontransformed control trees showed these symptoms as well as leaf distortions. Various categories of reactions were observed with the $\mathrm{R}_{0} \mathrm{CP}_{\mathrm{T}}$ and $\mathrm{CP}_{\mathrm{NT}}$ transgenic trees (Tables 1 and 2).

Three general types of reactions were observed in different $\mathrm{R}_{0} \mathrm{CP}_{\mathrm{T}}$ plants. These included: (i) no symptoms on leaves or fruits and no detectable virus titers in ELISA (optical density $[\mathrm{OD}]_{405 \mathrm{~nm}}$ values ranged from 0.000 to 0.058 ; values of negative and positive controls were 0.029 and 0.221 , respectively) (Fig. 1A), (ii) mild symptom expression, and (3) severe symptom expression similar to the non- 
transformed control trees (Table 1). Trees of all but one $\mathrm{R}_{0} \mathrm{CP}_{\mathrm{T}}$ transgenic line (line 52.5) did not show signs of disease infection. Trees of a few $\mathrm{R}_{0} \mathrm{CP}_{\mathrm{T}}$ lines developed mild or attenuated symptom expression (lines 52.2 and 52.24) at a similar rate to the susceptible nontransformed control trees or delayed symptom expression after the controls (line 52.22). Except for one line that was susceptible, trees of the $\mathrm{R}_{0}$ $\mathrm{CP}_{\mathrm{T}}$ lines showed more than one reaction in the field.

Tree and fruit characteristics of $\mathrm{R}_{0}$ transgenic and nontransformed Sunrise solo papayas were also observed and are summarized in Table $1 . \mathrm{R}_{0} \mathrm{CP}_{\mathrm{T}}$ trees, with smaller trunk girth, produced red fleshed fruits with lower TSS and average weights that were the same or lower than the Sunrise solo controls. Fruit pulp samples tested negative for CP and NPTII proteins in ELISA; variable GUS activity was obtained in histochemical assays (Table 3 ). Likewise, CP protein was not detected in leaf samples of $\mathrm{R}_{0} \mathrm{CP}_{\mathrm{T}}$ lines $\left(\mathrm{OD}_{405 \mathrm{~nm}}\right.$ readings ranged from 0.000 to 0.018 ), but NPTII protein and GUS activity were detected in these samples. NPTII protein was detected in leaf samples of all the lines $\left(\mathrm{OD}_{405 \mathrm{~nm}}\right.$ readings ranged from 0.100 to 0.325 , absorbance readings of the positive controls averaged 1.124 and 0.308 in CP-
ELISA and NPTII-ELISA, respectively) and GUS activity in $83 \%$ of the lines. Staminate $\left(\delta^{\Uparrow}\right)$ trees were observed with some of $\mathrm{R}_{0} \mathrm{CP}_{\mathrm{T}}$ transgenic lines $(5 \%)$.

Similar reactions were observed with $\mathrm{R}_{0}$ $\mathrm{CP}_{\mathrm{NT}}$ lines, but the range and incidence differed from those observed with $\mathrm{R}_{0} \mathrm{CP}_{\mathrm{T}}$ lines (Table 2). Two trees of two $\mathrm{R}_{0} \mathrm{CP}_{\mathrm{NT}}$ lines (lines 28.2 and 32.1) were asymptomatic (for up to 14 months in the field, after which they were removed due to root rot infections). All other $\mathrm{R}_{0} \mathrm{CP}_{\mathrm{NT}}$ lines either exhibited mild infections (Fig. 1B) or delayed symptom expression, had both of these reactions, and a recovery phenotype manifested as mild reactions follow-

Table 1. Performance of first generation translatable coat protein $\left(\mathrm{R}_{0} \mathrm{CP}_{\mathrm{T}}\right)$ transgenic and nontransformed $\left(\mathrm{SR}_{1}\right)$ papayas under field conditions

\begin{tabular}{|c|c|c|c|c|c|c|c|c|c|c|c|c|}
\hline \multirow[b]{3}{*}{ Line } & \multirow{2}{*}{\multicolumn{6}{|c|}{ Incidence of PRSV }} & \multicolumn{2}{|c|}{ Tree characteristics $^{\mathbf{b}}$} & \multicolumn{4}{|c|}{ Fruit characteristics ${ }^{\mathrm{c}}$} \\
\hline & & & & & & & \multirow{2}{*}{$\begin{array}{l}\text { Trunk } \\
\text { girth }\end{array}$} & \multirow{2}{*}{$\begin{array}{c}\text { Height to } \\
\text { 1st fruit }\end{array}$} & \multirow[b]{2}{*}{ Weight (kg) } & \multirow{2}{*}{$\begin{array}{l}\text { Shape } \\
\text { index }\end{array}$} & \multirow{2}{*}{$\begin{array}{l}\text { Flesh } \\
\text { color }\end{array}$} & \multirow[b]{2}{*}{ TSS $(\%)$} \\
\hline & $\mathbf{S}_{\mathbf{S}}$ & $\mathbf{S}_{\mathrm{D}}$ & $\mathbf{S}_{\mathrm{A}}$ & $\mathbf{S}_{\mathbf{D A}}$ & $\mathbf{S}_{\mathbf{R}}$ & NS & & & & & & \\
\hline$\overline{52.2}$ & $0 / 9$ & $0 / 9$ & $1 / 9$ & $0 / 9$ & $0 / 9$ & $8 / 9$ & $26^{*}$ & $1.28 * *$ & $0.40 *$ & $1.48^{* * *}$ & $\mathrm{R}$ & $12.7^{*}$ \\
\hline 52.3 & $1 / 4$ & $0 / 4$ & $0 / 4$ & $0 / 4$ & $0 / 4$ & $3 / 4$ & $27^{*}$ & $0.89 *$ & $0.31 *$ & $1.38^{* *}$ & $\mathrm{R}$ & $11.5^{*}$ \\
\hline 52.22 & $1 / 10$ & $0 / 10$ & $0 / 10$ & $2 / 10$ & $0 / 10$ & $7 / 10$ & $26 *$ & $1.28 * *$ & $0.28 *$ & $1.43^{* *}$ & $\mathrm{R}$ & $12.8^{*}$ \\
\hline 53.1 & $2 / 5$ & $0 / 5$ & $0 / 5$ & $0 / 5$ & $0 / 5$ & $3 / 5$ & $24 *$ & 1.04 & $0.40 *$ & $1.16^{*}$ & $\mathrm{R}$ & 12.9 \\
\hline 52.24 & $0 / 2$ & $0 / 2$ & $1 / 2$ & $0 / 2$ & $0 / 2$ & $1 / 2$ & $26^{*}$ & 1.10 & $0.33^{*}$ & $1.19^{*}$ & $\mathrm{R}$ & $12.6^{*}$ \\
\hline 52.5 & $2 / 2$ & $0 / 2$ & $0 / 2$ & $0 / 2$ & $0 / 2$ & $0 / 2$ & $24 *$ & $1.30 * *$ & 0.44 & $1.15^{*}$ & $\mathrm{R}$ & $13.8^{* *}$ \\
\hline $\mathrm{SR}_{1}$ & $33 / 33$ & $0 / 33$ & $0 / 33$ & $0 / 33$ & $0 / 33$ & $0 / 33$ & 36 & 1.03 & 0.43 & 1.29 & $\mathrm{R}$ & 12.9 \\
\hline
\end{tabular}

${ }^{a}$ Reactions to field infections were grouped into categories according to symptom expression: $\mathrm{S}_{\mathrm{S}}=$ severe mosaic on foliage, reduction or deformation of leaves, and or fruits covered with ringspot blemishes, $S_{D}=$ severe symptoms on foliage or fruits after 14 to 21 months, $S_{A}=$ mild or attenuated mosaic on foliage, $S_{\mathrm{DA}}=$ mild or attenuated mosaic on foliage after 14 to 21 months, $S_{\mathrm{R}}=$ recovery from severe symptoms, and NS = no symptom expression on foliage or fruits. Data are given as number of trees showing the phenotype to total number in the field plot; lines are arranged from least to most severe response to Papaya ringspot virus (PRSV).

${ }^{\mathrm{b}}$ Data on trunk girth $(\mathrm{cm})$ and height to first fruit $(\mathrm{m})$ were observed at 6 months postplanting. Mean values are the same as the Sunrise solo controls (no asterisk), significantly higher (**), or significantly lower (*) at $P=0.05$ using the $t$ test.

${ }^{\mathrm{c}}$ Weights $(\mathrm{kg})$ and shape index (length to width ratio in $\mathrm{cm}$ ) were determined at commercial maturity of fruits whereas flesh color $(\mathrm{R}=\mathrm{red} / \mathrm{orange}$ and $\mathrm{Y}=$ yellow) and TSS (\% total soluble solids) were determined at eating maturity.

Table 2. Performance of first generation nontranslatable coat protein $\left(\mathrm{R}_{0} \mathrm{CP}_{\mathrm{NT}}\right)$ transgenic and nontransformed $\left(\mathrm{SR}_{1}\right)$ papayas under field conditions

\begin{tabular}{|c|c|c|c|c|c|c|c|c|c|c|c|c|}
\hline \multirow[b]{3}{*}{ Line } & \multirow{2}{*}{\multicolumn{6}{|c|}{ Incidence of PRSV }} & \multicolumn{2}{|c|}{ Tree characteristics $^{b}$} & \multicolumn{4}{|c|}{ Fruit characteristics ${ }^{\mathrm{c}}$} \\
\hline & & & & & & & \multirow{2}{*}{$\begin{array}{l}\text { Trunk } \\
\text { girth }\end{array}$} & \multirow{2}{*}{$\begin{array}{c}\text { Height to } \\
\text { 1st fruit }\end{array}$} & \multirow{2}{*}{$\begin{array}{c}\text { Weight } \\
\text { (kg) }\end{array}$} & \multirow{2}{*}{$\begin{array}{l}\text { Shape } \\
\text { index }\end{array}$} & \multirow{2}{*}{$\begin{array}{l}\text { Flesh } \\
\text { color }\end{array}$} & \multirow{2}{*}{$\begin{array}{l}\text { TSS } \\
(\%)\end{array}$} \\
\hline & $\mathbf{S}_{\mathrm{S}}$ & $\mathbf{S}_{\mathrm{D}}$ & $\mathbf{S}_{\mathrm{A}}$ & $\mathbf{S}_{\mathrm{DA}}$ & $\mathbf{S}_{\mathbf{R}}$ & NS & & & & & & \\
\hline 28.2 & $7 / 10$ & $1 / 10$ & $0 / 10$ & $1 / 10$ & $0 / 10$ & $1 / 10$ & $27^{*}$ & $1.16^{* *}$ & $0.32 *$ & $1.42 * *$ & $\mathrm{R}$ & 13.1 \\
\hline 32.1 & $0 / 1$ & $0 / 1$ & $0 / 1$ & $0 / 1$ & $0 / 1$ & $1 / 1$ & $22 *$ & $\mathrm{na}^{\mathrm{d}}$ & na & $1.38 * *$ & $\mathrm{R}$ & na \\
\hline 32.15 & $0 / 8$ & $7 / 8$ & $0 / 8$ & $1 / 8$ & $0 / 8$ & $0 / 8$ & $29 *$ & - & - & - & - & - \\
\hline 26.1 & $0 / 6$ & $1 / 6$ & $1 / 6$ & $4 / 6$ & $0 / 6$ & $0 / 6$ & $35^{*}$ & $1.09 * *$ & $0.53 * *$ & $1.64 * *$ & Y & $12.1^{*}$ \\
\hline 21.12 & $0 / 2$ & $0 / 2$ & $2 / 2$ & $0 / 2$ & $0 / 2$ & $0 / 2$ & $18 *$ & $0.76^{*}$ & $0.12 *$ & $1.20 *$ & Y & na \\
\hline 20.6 & $0 / 1$ & $0 / 1$ & $1 / 1$ & $0 / 1$ & $0 / 1$ & $0 / 1$ & $29 *$ & $1.29 * *$ & $1.50 * *$ & $1.00 *$ & Y & na \\
\hline 5.175 .4 & $1 / 2$ & $0 / 2$ & $1 / 2$ & $0 / 2$ & $0 / 2$ & $0 / 2$ & $28 *$ & $1.28 * *$ & $0.70 * *$ & $1.14^{*}$ & $\mathrm{Y}$ & $6.5^{*}$ \\
\hline 21.20 & $2 / 4$ & $0 / 4$ & $0 / 4$ & $0 / 4$ & $2 / 4$ & $0 / 4$ & $33^{*}$ & $0.89^{*}$ & $0.35^{*}$ & $1.24 *$ & Y & $10.4^{*}$ \\
\hline 21.10 & $5 / 8$ & $0 / 8$ & $0 / 8$ & $0 / 8$ & $3 / 8$ & $0 / 8$ & $29 *$ & $0.80 *$ & $0.51 * *$ & $1.28^{*}$ & $\mathrm{Y}$ & $12.0^{*}$ \\
\hline 21.21 & $7 / 11$ & $2 / 11$ & $0 / 11$ & $0 / 11$ & $2 / 11$ & $0 / 11$ & $29 *$ & $0.75^{*}$ & $0.51 * *$ & $1.25^{*}$ & Y & $10.7^{*}$ \\
\hline 21.7 & $10 / 11$ & $0 / 11$ & $0 / 11$ & $1 / 11$ & $0 / 11$ & $0 / 11$ & $30^{*}$ & $0.84^{*}$ & $0.61 * *$ & $1.21 *$ & Y & $12.2^{*}$ \\
\hline $\begin{array}{l}3.175 .15, \\
13.175 .15, \\
18.1,21.13, \\
21.14,21.19, \\
21.4,32.11, \\
32.3\end{array}$ & $20 / 20$ & $0 / 20$ & $0 / 20$ & $0 / 20$ & $0 / 20$ & $0 / 20$ & - & - & - & - & - & - \\
\hline $\mathrm{SR}_{1}$ & $33 / 33$ & $0 / 33$ & $0 / 33$ & $0 / 33$ & $0 / 33$ & $0 / 33$ & 36 & 1.03 & 0.43 & 1.29 & $\mathrm{R}$ & 12.8 \\
\hline
\end{tabular}

${ }^{a}$ Reactions to field infections were grouped into categories according to symptom expression: $\mathrm{S}_{\mathrm{S}}=$ severe mosaic on foliage, reduction or deformation of leaves, and or fruits covered with ringspot blemishes, $\mathrm{S}_{\mathrm{D}}=$ severe symptoms on foliage or fruits after 14 to 21 months, $\mathrm{S}_{\mathrm{A}}=$ mild or attenuated mosaic on foliage, $S_{\mathrm{DA}}=$ mild or attenuated mosaic on foliage after 14 to 21 months, $S_{\mathrm{R}}=$ recovery from severe symptoms, and NS = no symptom expression on foliage or fruits. Data are given as number of trees showing the phenotype to total number in the field plot; lines are arranged from least to most severe response to Papaya ringspot virus (PRSV).

${ }^{b}$ Data on trunk girth $(\mathrm{cm})$ and height to first fruit $(\mathrm{m})$ were observed at 6 months postplanting. Mean values are the same as the Sunrise solo controls (no asterisk), significantly higher (**), or significantly lower $(*)$ at $P=0.05$ using the $t$ test.

${ }^{\mathrm{c}}$ Weights $(\mathrm{kg})$ and shape index (length to width ratio in $\mathrm{cm}$ ) were determined at commercial maturity of fruits, whereas flesh color $(\mathrm{R}=\mathrm{red} / \mathrm{orange}$ and $\mathrm{Y}=$ yellow) and TSS (\% total soluble solids) were determined at eating maturity.

$\mathrm{d}$ na $=$ not assessed; $-=$ not applicable. 
ing an initial susceptible reaction or susceptibility equal to the nontransformed control trees (Table 2). Sixty-two percent of the $\mathrm{CP}_{\mathrm{NT}}$ trees showed the latter reaction compared with $19 \%$ of the $\mathrm{R}_{0} \mathrm{CP}_{\mathrm{T}}$ trees; $35 \%$ of the $\mathrm{R}_{0} \mathrm{CP}_{\mathrm{NT}}$ trees showed the former reactions compared with $25 \%$ of the $\mathrm{R}_{0} \mathrm{CP}_{\mathrm{T}}$ trees. None of the $\mathrm{R}_{0} \mathrm{CP}_{\mathrm{T}}$ trees showed the recovery phenotype (Table 1).

A number of $\mathrm{R}_{0} \mathrm{CP}_{\mathrm{NT}}$ trees were also dioecious (separate $\hat{\delta}$ and $q$ trees) and did not increase in trunk girth as the nontransformed trees (Table 2). They produced mostly large, yellow fleshed fruits with lower TSS than the controls. Neither CP nor NPTII was detected in fruits from these trees; however, variable GUS activity was observed (Table 3). NPTII protein was detected in leaf samples of all lines and GUS activity in $35 \%$ of the lines; CP was not detected.

In some instances, $R_{1}$ progenies showed reactions previously observed with parent $\mathrm{R}_{0}$ trees. However, in other instances, the reaction was classified in a category that was not previously observed with the $\mathrm{R}_{0}$ generation, or the incidence of the reaction was lower in the $R_{1}$ progenies. Tables 4 and 5 summarize results based on visual symptoms and CP-ELISA.

In general, a lower incidence of symptomless $\mathrm{R}_{1} \mathrm{CP}_{\mathrm{T}}$ trees or trees with attenuated symptoms was observed in all but one line (line 52.22, Table 4). Some progenies of all $\mathrm{R}_{1} \mathrm{CP}_{\mathrm{T}}$ lines showed the susceptible phenotype. Symptomless trees of $\mathrm{R}_{1} \mathrm{CP}_{\mathrm{T}}$ lines 52.3 and 52.24 , as well as trees that
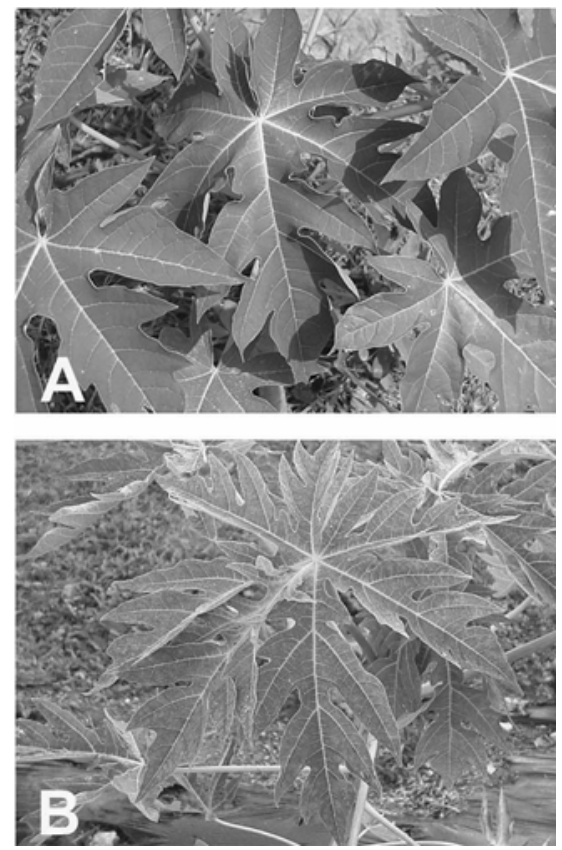

Fig. 1. Reactions of transgenic papayas to field infection. A, Resistant response of transgenic line 52.3 carrying the translatable coat protein $\left(\mathrm{CP}_{\mathrm{T}}\right)$ gene. $\mathbf{B}$, Mild systemic infection of line 26.1 carrying the nontranslatable $\mathrm{CP}_{\mathrm{NT}}$ gene (note vein-clearing and mild discoloration). exhibited mild infections, produced fruits with TSS within the range required for the export market, shape indices of 1.09 to 1.22 (Fig. 2A), but average weights of fruits from line 52.3 were lower than those of the controls (Table 4). A general improvement in the trunk girth was also observed. Unlike with $\mathrm{R}_{0}$ samples, GUS activity was consistently detected in fruit samples from $\mathrm{R}_{1} \mathrm{CP}_{\mathrm{T}}$ progenies of three lines; CP and NPTII were not detected (Table 3). NPTII (all lines) and GUS activity $(83 \%)$ were detected in leaf samples but not $\mathrm{CP}$. Unproductive staminate trees were noted $(21 \%)$.

Although more $\mathrm{R}_{1} \mathrm{CP}_{\mathrm{NT}}$ trees showed mild reactions or delayed reactions, no tree remained symptomless for the duration of the field test (Table 5). In addition, mild reactions were observed with $\mathrm{R}_{1} \mathrm{CP}_{\mathrm{NT}}$ trees derived from susceptible parents (e.g., lines 21.14 and 13.175.15). The converse also was observed, where progenies of lines that previously exhibited no symptoms, mild or delayed symptom expression were as susceptible to infection as nontransformed controls (line 32.15), showed a delay in symptom expression (line 21.12), or showed a combination of the two reactions (lines 28.2, 32.1, 20.6, and 5.175.4). Progenies of three lines gave the same response of mild or delayed symptom expression (lines 21.7, 21.21, and 26.1) and seven lines the same susceptible response to field infection over both generations (Table 5). While asymptomatic or mild reacting trees of $\mathrm{R}_{1} \mathrm{CP}_{\mathrm{T}}$ lines showed suitable characteristics for the export market, mild reacting $\mathrm{R}_{1} \mathrm{CP}_{\mathrm{NT}}$ lines were more suited for the local market (Fig. 2B). The latter trees mostly produced fruits of red or yellow flesh with average weights up to one and a half times the weights of fruits from control trees; based on TSS $(\geq 12 \%)$, $70 \%$ of the lines produced fruits of good quality (Table 5). CP and NPTII proteins were not detected in ELISA with fruit samples, but GUS activity was consistently observed with samples from two lines (Table 3). While NPTII protein (all samples) and GUS activity (25\%) were detected in leaf samples of $\mathrm{R}_{1} \mathrm{CP}_{\mathrm{NT}}$ plants $\left(\mathrm{OD}_{405 \mathrm{~nm}}\right.$ readings $\left.\geq 0.100\right)$, CP was never detected in these samples $\left(\mathrm{OD}_{405 \mathrm{~nm}}\right.$ readings ranged from 0.000 to 0.020 ). Absorbance readings of the positive controls averaged 0.832 and 0.803 in CP-ELISA and NPTII-ELISA, respectively. Staminate trees were again observed (33\%).

All nontransformed trees developed severe symptoms within 13 months; however, various reactions were obtained with NPTII-negative trees (Table 6). Nine lines showed attenuated symptoms and three lines appeared asymptomatic. At 17 months, five lines showed mild symptoms which were comparable to or better than the performance of the NPTII-positive plants (e.g., lines 21.7 and 26.1). Interestingly, the mild reaction at 17 months was observed with more NPTII-negative plants derived from parent $\mathrm{CP}_{\mathrm{NT}}$ lines (Table 3). Attenuated symptoms of the remaining trees progressed to more severe infections (Table 6).

Table 3. Detection of transgene expression products in mature transgenic fruits

\begin{tabular}{|c|c|c|c|c|c|c|c|}
\hline \multirow[b]{3}{*}{ Line } & & \multicolumn{6}{|c|}{ Transgene expression $^{a}$} \\
\hline & & \multicolumn{3}{|c|}{$\mathbf{R}_{\mathbf{0}}$} & \multicolumn{3}{|c|}{$\mathbf{R}_{1}$} \\
\hline & & $\mathbf{C P}$ & NPTII & GUS & $\mathbf{C P}$ & NPTII & GUS \\
\hline \multirow{4}{*}{$\overline{\mathrm{CP}_{\mathrm{T}}}$} & 52.2 & 0.001 & 0.000 & \pm & 0.010 & 0.000 & - \\
\hline & 52.22 & 0.000 & 0.014 & \pm & 0.006 & 0.014 & - \\
\hline & 52.24 & 0.007 & 0.011 & \pm & 0.007 & 0.011 & \pm \\
\hline & 52.3 & 0.000 & 0.001 & \pm & 0.004 & 0.001 & + \\
\hline \multirow{12}{*}{$\mathrm{CP}_{\mathrm{NT}}$} & 5.175 .4 & $\mathrm{na}^{\mathrm{b}}$ & 0.000 & \pm & na & na & + \\
\hline & 13.175 .15 & na & na & na & na & na & + \\
\hline & 21.10 & 0.000 & 0.000 & - & 0.011 & 0.000 & - \\
\hline & 21.12 & na & 0.000 & \pm & na & 0.000 & \pm \\
\hline & 21.14 & na & 0.000 & \pm & na & na & - \\
\hline & 21.20 & na & 0.000 & \pm & 0.019 & 0.047 & \pm \\
\hline & 21.21 & na & 0.000 & \pm & 0.003 & 0.008 & - \\
\hline & 21.4 & na & na & \pm & 0.002 & 0.010 & \pm \\
\hline & 21.7 & na & 0.000 & \pm & na & 0.000 & \pm \\
\hline & 26.1 & 0.000 & 0.000 & + & 0.000 & 0.026 & \pm \\
\hline & 28.2 & 0.010 & 0.000 & \pm & 0.000 & 0.002 & \pm \\
\hline & 32.1 & na & na & na & na & na & \pm \\
\hline $\mathrm{SR}_{2}$ & - & 0.000 & 0.000 & - & 0.008 & 0.000 & - \\
\hline
\end{tabular}

${ }^{a}$ Coat protein $(\mathrm{CP})$ and NPTII proteins were tested by double-antibody sandwich enzyme-linked immunosorbent assay (DAS-ELISA). Data are reported as the average optical density $(\mathrm{OD})_{405 \mathrm{~nm}}$ values of 3 to 19 fruits per genotype/line. Positive controls in CP and NPTII assays gave OD $_{405 \mathrm{~nm}}$ absorbance readings between 0.250 and $0.411(0.03$ to $0.75 \mathrm{ng})$ and 0.281 to $0.538(0.03$ to $0.15 \mathrm{ng})$, respectively. $\mathrm{OD}_{405 \mathrm{~nm}}$ absorbance readings of negative controls in CP-ELISA ranged from 0.004 to 0.014 and averaged 0.012 in NPTII-ELISA. Activity of GUS protein was detected in histochemical assays. Results of the histochemical assays are reported as the observation of blue hydrolysis products $(+)$, no blue products $(-)$, or inconsistent observation of hydrolysis products $( \pm$ ) with 3 to 54 fruits per genotype. Blue hydrolysis products were obtained with positive controls (2-3 U $\beta$-glucuronidase enzyme).

${ }^{\mathrm{b}}$ na $=$ not assessed. 


\section{DISCUSSION}

Transgenic papaya lines carrying $\mathrm{CP}_{\mathrm{T}}$ or $\mathrm{CP}_{\mathrm{NT}}$ constructs were field tested over two generations in a commercial papayagrowing region in Jamaica under high PRSV pressure. Trees with acceptable horticultural characteristics exhibited various reactions to PRSV that included no symptoms, mild or severe symptoms, or combinations of all three reactions.

Different reactions were observed between transgenic lines carrying either the $\mathrm{CP}_{\mathrm{T}}$ or $\mathrm{CP}_{\mathrm{NT}}$ gene under high disease pressure. Some lines transformed with the $\mathrm{CP}_{\mathrm{T}}$ gene exhibited mild symptoms to no symptoms in the field (as well as no detectable virus titer, e.g., lines 52.3 and 52.24 in
Table 4) and were therefore moderately resistant to PRSV, while other lines were as susceptible as the nontransformed controls. $\mathrm{CP}_{\mathrm{NT}}$ lines were mostly susceptible in the field, although some lines exhibited a delayed symptom expression. Some $\mathrm{CP}_{\mathrm{NT}}$ lines showed mild reactions in the field and could be considered weakly resistant (e.g., lines 21.7, 21.10, and 21.21 in Table 5). These lines could also be regarded as tolerant to PRSV infection given the continued production of acceptable fruits during the field test.

A concern of whether the asymptomatic response was due to escaped infection was further investigated under greenhouse conditions, given the stipulation by the NBC that no mechanical inoculations were to be conducted at the field site. Progenies $\left(\mathrm{R}_{3}\right)$ of these trees were mechanically inoculated with virus collected from the plot (two times over 6 to 8 weeks); the same range in reactions was observed, that is, no symptom expression, delayed expression, or severe symptom expression (M. M. Chin and P. Tennant, unpublished data).

The variations in reactions between lines carrying the $\mathrm{CP}_{\mathrm{T}}$ or $\mathrm{CP}_{\mathrm{NT}}$ gene construct, and within and between generations have been obtained in other studies with transgenic papaya. $\mathrm{R}_{0} \mathrm{CP}_{\mathrm{T}}$ plants developed in Australia, Florida, and Taiwan from local severe PSRV isolates imparted $0-15-100 \%$, $3-5-16 \%$, and $40-70-80 \%$ resistance to

Table 4. Phenotypes of second generation translatable coat protein $\left(\mathrm{R}_{1} \mathrm{CP}_{\mathrm{T}}\right)$ transgenic and nontransformed $(\mathrm{SR})$ papayas

\begin{tabular}{|c|c|c|c|c|c|c|c|c|c|c|c|c|}
\hline \multirow[b]{3}{*}{ Line } & \multirow{2}{*}{\multicolumn{6}{|c|}{ Incidence of PRSVa }} & \multicolumn{2}{|c|}{ Tree characteristics ${ }^{b}$} & \multicolumn{4}{|c|}{ Fruit characteristics $^{c}$} \\
\hline & & & & & & & \multirow{2}{*}{$\begin{array}{c}\text { Trunk } \\
\text { girth }\end{array}$} & \multirow{2}{*}{$\begin{array}{c}\text { Height to } \\
\text { 1st fruit }\end{array}$} & \multirow{2}{*}{$\begin{array}{c}\text { Weight } \\
\text { (kg) }\end{array}$} & \multirow{2}{*}{$\begin{array}{l}\text { Shape } \\
\text { index }\end{array}$} & \multirow{2}{*}{$\begin{array}{l}\text { Flesh } \\
\text { color }\end{array}$} & \multirow{2}{*}{$\begin{array}{l}\text { TSS } \\
(\%)\end{array}$} \\
\hline & $\mathbf{S}_{\mathrm{S}}$ & $\mathbf{S}_{\mathrm{D}}$ & $\mathbf{S}_{\mathrm{A}}$ & $\mathbf{S}_{\mathrm{DA}}$ & $\mathbf{S}_{\mathbf{R}}$ & NS & & & & & & \\
\hline 52.2 & $3 / 5$ & $2 / 5$ & $0 / 5$ & $0 / 5$ & $0 / 5$ & $0 / 5$ & $45^{* *}$ & $1.04 *$ & $0.29 *$ & $1.26 * *$ & $\mathrm{R}-\mathrm{Y}$ & $13.7^{* *}$ \\
\hline 52.3 & $2 / 3$ & $0 / 3$ & $0 / 3$ & $0 / 3$ & $0 / 3$ & $1 / 3$ & $42 * *$ & $1.22 *$ & $0.34 *$ & $1.22 * *$ & $\mathrm{R}$ & $12.9^{* *}$ \\
\hline 52.22 & $4 / 7$ & $0 / 7$ & $0 / 7$ & $3 / 7$ & $0 / 7$ & $0 / 7$ & $46^{* *}$ & $1.01 *$ & $0.44 * *$ & $1.10^{*}$ & R-Y & $11.8 *$ \\
\hline 53.1 & $2 / 2$ & $0 / 2$ & $0 / 2$ & $0 / 2$ & $0 / 2$ & $0 / 2$ & ${ }^{\mathrm{d}}$ & - & - & - & - & - \\
\hline 52.24 & $5 / 7$ & $0 / 7$ & $0 / 7$ & $1 / 7$ & $0 / 7$ & $1 / 7$ & $30 *$ & $1.40 * *$ & $0.52 * *$ & $1.09 *$ & $\mathrm{R}$ & $11.5^{*}$ \\
\hline 52.5 & $2 / 2$ & $0 / 2$ & $0 / 2$ & $0 / 2$ & $0 / 2$ & $0 / 2$ & - & - & - & - & - & - \\
\hline $\mathrm{SR}_{2}$ & $15 / 15$ & $0 / 15$ & $0 / 15$ & $0 / 15$ & $0 / 15$ & $0 / 15$ & 38 & 1.22 & 0.42 & 1.15 & $\mathrm{R}$ & 12.5 \\
\hline
\end{tabular}

${ }^{a} S_{S}=$ severe mosaic on foliage, reduction or deformation of leaves, and or fruits covered with ringspot blemishes, $S_{D}=$ severe symptoms on foliage or fruits after 14 to 21 months, $S_{A}=$ mild or attenuated mosaic on foliage, $S_{D A}=$ mild or attenuated mosaic on foliage after 14 to 21 months, $S_{R}=$ recovery from severe symptoms, and NS = no symptom expression on foliage or fruits. Data are given as number of trees showing the phenotype to total number in the field plot.

${ }^{\mathrm{b}}$ Data on trunk girth $(\mathrm{cm})$ and height to first fruit $(\mathrm{m})$ were observed at 6 months postplanting. Mean values are the same as the Sunrise solo controls (no asterisk), significantly higher (**), or significantly lower (*) at $P=0.05$ using the $t$ test.

${ }^{c}$ Weights $(\mathrm{kg})$ and shape index (length to width ratio in $\mathrm{cm}$ ) were determined at commercial maturity of fruits, whereas flesh color $(\mathrm{R}=$ red/orange and $\mathrm{Y}=$ yellow) and TSS (\% total soluble solids) were determined at eating maturity.

$\mathrm{d}_{-}=$not applicable.

Table 5. Phenotypes of second generation nontranslatable coat protein $\left(\mathrm{R}_{1} \mathrm{CP}_{\mathrm{NT}}\right)$ transgenic and nontransformed papayas $\left(\mathrm{SR}_{2}\right)$

\begin{tabular}{|c|c|c|c|c|c|c|c|c|c|c|c|c|}
\hline \multirow[b]{3}{*}{ Line } & & & & & & & \multicolumn{2}{|c|}{ Tree characteristics $^{b}$} & \multicolumn{4}{|c|}{ Fruit characteristics ${ }^{c}$} \\
\hline & \multicolumn{6}{|c|}{ Incidence of PRSV ${ }^{a}$} & \multirow{2}{*}{$\begin{array}{l}\text { Trunk } \\
\text { girth }\end{array}$} & \multirow{2}{*}{$\begin{array}{c}\text { Height to } \\
\text { 1st fruit }\end{array}$} & \multirow{2}{*}{$\begin{array}{c}\text { Weight } \\
\text { (kg) }\end{array}$} & \multirow{2}{*}{$\begin{array}{l}\text { Shape } \\
\text { index }\end{array}$} & \multirow{2}{*}{$\begin{array}{l}\text { Flesh } \\
\text { color }\end{array}$} & \multirow{2}{*}{$\begin{array}{l}\text { TSS } \\
(\%)\end{array}$} \\
\hline & $\mathbf{S}_{\mathbf{S}}$ & $\mathbf{S}_{\mathbf{D}}$ & $\mathbf{S}_{\mathbf{A}}$ & $\mathbf{S}_{\mathbf{D A}}$ & $\mathbf{S}_{\mathbf{R}}$ & NS & & & & & & \\
\hline 28.2 & $2 / 4$ & $2 / 4$ & $0 / 4$ & $0 / 4$ & $0 / 4$ & $0 / 4$ & 35 & $1.26^{*}$ & $0.60 * *$ & $1.22 * *$ & R-Y & $10.9^{*}$ \\
\hline 32.1 & $3 / 4$ & $1 / 4$ & $0 / 4$ & $0 / 4$ & $0 / 4$ & $0 / 4$ & $\mathrm{na}^{\mathrm{d}}$ & na & $0.44 * *$ & $1.27 * *$ & R-Y & $14.9 * *$ \\
\hline 32.15 & $1 / 1$ & $0 / 1$ & $0 / 1$ & $0 / 1$ & $0 / 1$ & $0 / 1$ & - & - & - & - & - & - \\
\hline 26.1 & $3 / 4$ & $0 / 4$ & $1 / 4$ & $0 / 4$ & $0 / 4$ & $0 / 4$ & $32 *$ & $1.16^{*}$ & $0.49 * *$ & $1.13^{*}$ & $\mathrm{R}-\mathrm{Y}$ & $12.2 *$ \\
\hline 21.12 & $0 / 4$ & $4 / 4$ & $0 / 4$ & $0 / 4$ & $0 / 4$ & $0 / 4$ & $43 * *$ & $0.76^{*}$ & $0.70^{* * *}$ & $1.14^{*}$ & Y & $12.0^{*}$ \\
\hline 20.6 & $2 / 4$ & $2 / 4$ & $0 / 4$ & $0 / 4$ & $0 / 4$ & $0 / 4$ & 35 & $1.18 *$ & $0.09 *$ & $1.03 *$ & $\mathrm{Y}$ & $8.6^{*}$ \\
\hline 5.175 .4 & $1 / 4$ & $3 / 4$ & $0 / 4$ & $0 / 4$ & $0 / 4$ & $0 / 4$ & $34 *$ & $0.84 *$ & $0.54 * *$ & $1.06 *$ & $\mathrm{R}$ & $15.0^{* *}$ \\
\hline 21.20 & $0 / 4$ & $3 / 4$ & $0 / 4$ & $1 / 4$ & $0 / 4$ & $0 / 4$ & - & - & - & - & - & - \\
\hline 21.10 & $0 / 2$ & $0 / 2$ & $0 / 2$ & $0 / 2$ & $2 / 2$ & $0 / 2$ & $51 * *$ & $1.02 *$ & $0.69 * *$ & $1.13^{*}$ & $\mathrm{R}-\mathrm{Y}$ & $12.3^{*}$ \\
\hline 21.21 & $0 / 4$ & $3 / 4$ & $0 / 4$ & $1 / 4$ & $0 / 4$ & $0 / 4$ & $47 * *$ & $1.48 * *$ & $0.48 * *$ & $1.14^{*}$ & $\mathrm{R}-\mathrm{Y}$ & $8.5^{*}$ \\
\hline 21.7 & $1 / 4$ & $0 / 4$ & $0 / 4$ & $3 / 4$ & $0 / 4$ & $0 / 4$ & $30 *$ & na & na & 1.18 & na & $13.4 * *$ \\
\hline 13.175 .15 & $0 / 1$ & $1 / 1$ & $0 / 1$ & $0 / 1$ & $0 / 1$ & $0 / 1$ & $46 * *$ & $0.60 *$ & $0.32 *$ & $1.19 * *$ & R-Y & $16.4 * *$ \\
\hline 21.14 & $1 / 3$ & $0 / 3$ & $0 / 3$ & $2 / 3$ & $0 / 3$ & $0 / 3$ & $33 *$ & $1.18 *$ & $0.71 * *$ & $1.40 * *$ & $\mathrm{Y}$ & $15.0^{* * *}$ \\
\hline $\begin{array}{l}3.175 .15, \\
18.1,21.13, \\
21.19,21.4, \\
32.11,32.3\end{array}$ & $16 / 16$ & $0 / 16$ & $0 / 16$ & $0 / 16$ & $0 / 16$ & $0 / 16$ & - & - & - & - & - & - \\
\hline $\mathrm{SR}_{2}$ & $15 / 15$ & $0 / 15$ & $0 / 15$ & $0 / 15$ & $0 / 15$ & $0 / 15$ & 38 & 1.22 & 0.42 & 1.15 & $\mathrm{R}$ & 12.5 \\
\hline
\end{tabular}

${ }^{a} S_{S}=$ severe mosaic on foliage, reduction or deformation of leaves, and or fruits covered with ringspot blemishes, $\mathrm{S}_{\mathrm{D}}=$ severe symptoms on foliage or fruits after 14 to 21 months, $S_{A}=$ mild or attenuated mosaic on foliage, $S_{D A}=$ mild or attenuated mosaic on foliage after 14 to 21 months, $S_{R}=$ recovery from severe symptoms, and NS = no symptom expression on foliage or fruits. Data are given as number of trees showing the phenotype to total number in the field plot.

${ }^{\mathrm{b}}$ Data on trunk girth $(\mathrm{cm})$ and height to first fruit $(\mathrm{m})$ were observed at 6 months postplanting. Mean values are the same as the Sunrise solo controls (no asterisk), significantly higher (**), or significantly lower $(*)$ at $P=0.05$ using the $t$ test.

$\mathrm{c}$ Weights $(\mathrm{kg})$ and shape index (length to width ratio in $\mathrm{cm})$ were determined at commercial maturity of fruits, whereas flesh color $(\mathrm{R}=\mathrm{red} / \mathrm{orange}$ and $\mathrm{Y}=$ yellow) and TSS (\% total soluble solids) were determined at eating maturity.

$\mathrm{d}$ na $=$ not assessed; $-=$ not applicable. 
challenge infections $(1,3,16)$. Resistance of $\mathrm{CP}_{\mathrm{T}} \mathrm{R}_{1}$ progenies for Taiwan ranged from 51 to $74 \%$ (1). Floridian $\mathrm{CP}_{\mathrm{NT}}$ plants carrying either an antisense $\mathrm{CP}_{\mathrm{T}}$ or $\mathrm{CP}_{\mathrm{NT}}$ with three inframe stop codons conferred higher levels of resistance in the $\mathrm{R}_{0}$ generation than the $\mathrm{CP}_{\mathrm{T}}$ construct and levels of 24 to $88 \%$ in the $\mathrm{R}_{1}$ generation (3). Although all $\mathrm{R}_{0}$ transgenic lines transformed with severe $\mathrm{CP}_{\mathrm{T}}$ from Vigia $(\mathrm{EV})$ and Lagunillas (LA), Venezuela, were completely resistant to mechanical challenge with LA, resistance ranged from 2 to $51 \%$ in $\mathrm{R}_{1}$ progenies following inoculations with $\mathrm{EV}$ and LA (7). Interestingly, complete resistance or immunity was reported with Hawaiian $\mathrm{R}_{0}$ and $\mathrm{R}_{1}$ transgenic lines transformed with the $\mathrm{CP}_{\mathrm{T}}$ from a mild mutant PRSV strain $(8,9,17)$. However, lines containing a $\mathrm{CP}_{\mathrm{NT}}$ version of the same gene conferred varying degrees of resistance $(2,6,11)$. Twenty-two of 77 lines conferred complete resistance against the homologous progeni-
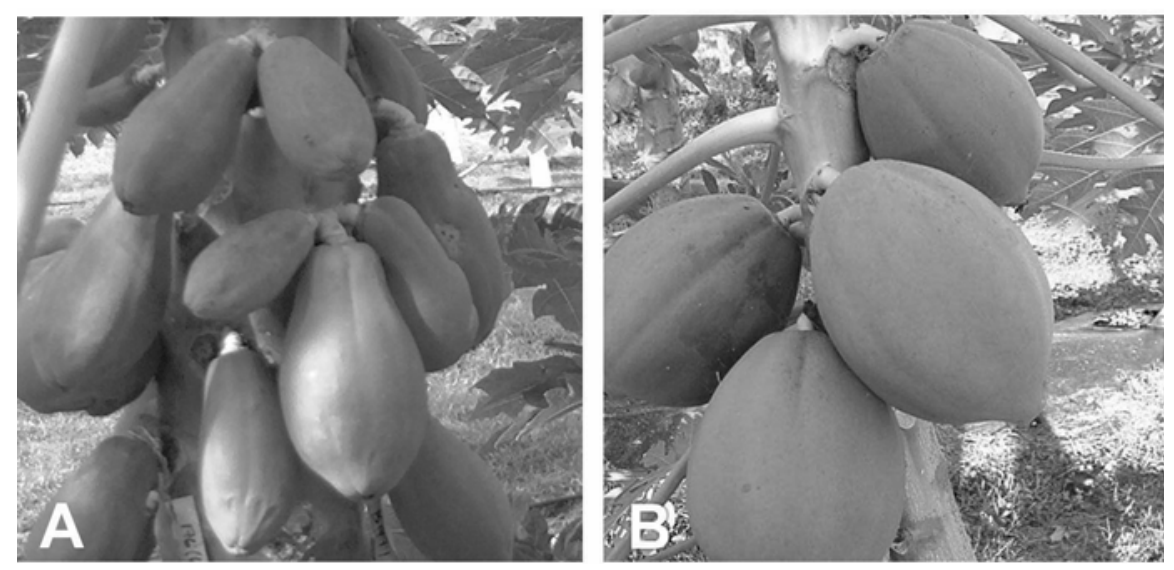

Fig. 2. Fruits of transgenic papaya trees. A, Pear-shaped fruits of transgenic line designation 52. B, Oblong-shaped fruits of line designation 26.

Table 6. Reactions of selected second generation $\left(R_{1}\right)$ NPTII-negative plants to field infections

\begin{tabular}{|c|c|c|c|c|c|c|}
\hline \multirow[b]{3}{*}{ Line } & \multicolumn{6}{|c|}{ Reaction to PRSV ${ }^{a}$} \\
\hline & \multicolumn{3}{|c|}{13 months } & \multicolumn{3}{|c|}{17 months } \\
\hline & $\mathbf{S}_{\mathrm{S}}$ & $\mathbf{S}_{\mathrm{A}}$ & NS & $\mathbf{S}_{\mathrm{S}}$ & $\mathbf{S}_{\mathrm{A}}$ & NS \\
\hline 52.24 & $2 / 3$ & $1 / 3$ & $0 / 3$ & $3 / 3$ & $0 / 3$ & $0 / 3$ \\
\hline 52.3 & $3 / 4$ & $1 / 4$ & $0 / 4$ & $3 / 3$ & $0 / 3$ & $0 / 3$ \\
\hline 5.175 .4 & $2 / 4$ & $2 / 4$ & $0 / 4$ & $4 / 4$ & $0 / 4$ & $0 / 4$ \\
\hline 20.6 & $2 / 4$ & $2 / 4$ & $0 / 4$ & $4 / 4$ & $0 / 4$ & $0 / 4$ \\
\hline 21.10 & $2 / 3$ & $0 / 3$ & $1 / 3$ & $1 / 2$ & $1 / 2$ & $0 / 2$ \\
\hline 21.12 & $2 / 4$ & $0 / 4$ & $2 / 4$ & $3 / 3$ & $0 / 3$ & $0 / 3$ \\
\hline 21.14 & $2 / 4$ & $2 / 4$ & $0 / 4$ & $2 / 4$ & $2 / 4$ & $0 / 4$ \\
\hline 21.21 & $3 / 4$ & $0 / 4$ & $1 / 4$ & $3 / 4$ & $1 / 4$ & $0 / 4$ \\
\hline 21.7 & $1 / 2$ & $1 / 2$ & $0 / 2$ & $1 / 2$ & $1 / 2$ & $0 / 2$ \\
\hline 26.1 & $2 / 3$ & $1 / 3$ & $0 / 3$ & $0 / 1$ & $1 / 1$ & $0 / 1$ \\
\hline 32.1 & $3 / 4$ & $1 / 4$ & $0 / 4$ & $4 / 4$ & $0 / 4$ & $0 / 4$ \\
\hline 32.3 & $2 / 4$ & $2 / 4$ & $0 / 4$ & $3 / 3$ & $0 / 3$ & $0 / 3$ \\
\hline $\mathrm{SR}_{2}$ & $15 / 15$ & $0 / 15$ & $0 / 15$ & $15 / 15$ & $0 / 15$ & $0 / 15$ \\
\hline
\end{tabular}

a Papaya seedlings were tested for the NPTII protein in enzyme-linked immunosorbent assay (ELISA). Samples with optical density $(\mathrm{OD})_{405 \mathrm{~nm}}$ readings $\leq 0.100$ were negative for the NPTII protein. $\mathrm{S}_{\mathrm{S}}=$ severe mosaic patterns on foliage, reduction or deformation of leaves, fruits covered with ringspot blemishes), $\mathrm{S}_{\mathrm{A}}=$ attenuation of symptom expression on foliage or fruits and NS = no symptom expression on foliage or fruits. Data are given as number of trees showing the phenotype to total number in the field plot. Plants of lines 52.24 and 52.3 were derived from translatable coat protein $\left(\mathrm{CP}_{\mathrm{T}}\right)$ parents; all other plants were derived from nontranslatable coat protein $\left(\mathrm{CP}_{\mathrm{NT}}\right)$ parents. $\mathrm{SR}_{2}=$ nontransformed papayas. study) suggest that the resistance in our transgenic papaya is RNA-mediated. Further work is in progress with the Jamaican transgenic papaya to address the effects of age and challenge virus on resistance and the integrity of the transgene and insertion numbers. Southern analysis is to be used in the latter determination given the false negatives observed in the NPTII-ELISA in this study. Various studies describe silencing of the nptII gene in transgenic plants $(4,6)$, which invariably affects the accuracy of phenotypic characterizations.

The resistance exhibited by the Jamaican transgenic papaya lines may be useful for commercial production, and efforts are presently focused on stabilizing interesting lines by continued self-pollination and crossing with true breeding Sunrise solo trees. The latter is necessary because the number of staminate ( $\delta$ ) trees in the $\mathrm{R}_{0}$ and $\mathrm{R}_{1}$ testing indicate that a true breeding Sunrise solo cultivar was not used at the onset of the experiments even though fruits from bisexual trees were used. Papaya growers prefer pistillate $(+)$ and bisexual trees since they are the fruit bearing plants; furthermore, bisexual trees are preferred over pistillate trees given the production of pear-shaped fruits, a characteristic required for the export market (pistillate trees produce round fruits). Recent data show outcrossing in bisexual trees affects $5 \%$ of seed (15).

It is hoped that the PRSV-resistant traits (phenotypes) can be transferred to local papaya cultivars, namely the large-fruited Santa Cruz giant and Cedro, by conventional breeding methods. These cultivars are as susceptible to PRSV as the commercial Sunrise solo and are grown for the local market, particularly for the canning and baking industries. Based on the performance of some of the NPTII-negative plants, however, a gene-based selection assay rather than a protein-based selection assay would probably be useful for identifying transgenic progenies. Evaluation of the nutritive content of transgenic fruits is underway to further assess the quality and safety of the transgenic product and to fulfill requirements of the NBC. It is reassuring that neither CP nor NPTII protein products was detected in the edible pulp of fruits from the Jamaican transgenic papaya. ELISAs have been repeated recently using up to $50 \mathrm{~g}$ of concentrated fruit pulp, and similar results were obtained (M. M. Roberts, D. A. Minott, P. Tennant, and J. C. Jackson-Malete, unpublished data). It was surprising, however, that GUS activity was consistently detected in three transgenic lines.

The introduction of resistance to Papaya bunchy top disease may also be required since a number of the transgenic lines were very susceptible to this disease. This affected their performance during the field testing as evidenced in reduced vigor (small trunk girth), fruit size, and quality 
of fruits (e.g., lines 21.21 and 20.6). Papaya bunchy top is another decline disease of papaya that affects production in the region.

\section{ACKNOWLEDGMENTS}

This work was supported by grants from the Jamaica Agricultural Foundation (JADF), Technology Investment Fund (TIF), and International Foundation of Science (IFS). Gratitude is extended to Shawna-Gae Turner and Melaine Chin for technical assistance in the laboratory, Andre Jackson for assistance in the greenhouse, and Michael Pryce (Ministry of Agriculture) and Locksley Wates (JADF) for assistance with the field plots. Thanks to Gustavo Fermin (Pacific Basin Agricultural Research Center, ARS-USDA) for critical reading and contributions to the preparation of the manuscript and Vilma Gregory and Deon Mitchell (UWI Infocom Center) on the graphic arrangement.

\section{LITERATURE CITED}

1. Bau, H.-J., Cheng, Y.-H., Yu, T.-A., Yang, J.-S., and Yeh, S.-D. 2003. Broad-spectrum resistance to different geographic strains of Papaya ringspot virus in coat protein gene transgenic papaya. Phytopathology 93:112-120.

2. Cai, W., Gonsalves, C., Tennant, P., Fermin, G., Souza, M., Sarindu, N., Jan, F., Zhu, H., and Gonsalves, C. 1999. A protocol for efficient transformation and regeneration of Carica papaya L. In Vitro Cell. Dev. Biol. Plant 35:61-69.

3. Davis, M. J., and Ying, Z. 2004. Development of papaya breeding lines with transgenic resistance to Papaya ringspot virus. Plant Dis. 88:352-358.

4. Day, C., Lee, E., Kobayashi, J., Holappa, L., Albert, H., and Ow, D. 2000. Transgene integration into the same chromosome location can produce alleles that express at a predictable level, or alleles that are differentially silenced. Genes Development 14:2869-2880.

5. De La Rosa, M., and Lastra, R. 1983. Purification and partial characterization of Papaya ringspot virus. Phytopathol. Z. 106:329-336.

6. Fermin, G. 2002. Use, application and technology transfer of native and synthetic genes to engineering single and multiple transgenic viral resistance. Ph.D. thesis.
Cornell University, Ithaca, NY.

7. Fermin, G., Inglessis, V., Garboza, C., Rangel, S., Dagert, M., and Gonsalves, D. 2004. Engineered resistance against Papaya ringspot virus in Venezuelan transgenic papayas. Plant Dis. 88:516-522.

8. Ferreira, S. A., Pitz, K. Y., Manshardt, R., Zee, F., Fitch, M., and Gonsalves, C. 2002. Virus coat protein transgenic papaya provides practical control of Papaya ringspot virus in Hawaii. Plant Dis. 86:101-105.

9. Fitch, M., Manshardt, R., Gonsalves, D., Slightom, J., and Sanford, L. 1992. Virus resistant papaya derived from tissues bombarded with the coat protein gene of Papaya ringspot virus. Bio/Technology 10:1466-1472.

10. Gonsalves, D. 1994. Papaya diseases caused by viruses. Pages 67-68 in: Compendium of Tropical Fruit Diseases. R. C. Ploetz, G. A. Zentmyer, W. T. Nishijima, K. G. Rohrbach, and H. D. Ohr, eds. American Phytopathological Society, St. Paul, MN.

11. Gonsalves, D. 1998. Control of Papaya ringspot virus in papaya: A case study. Pages 415537 in: Annu. Rev. Phytopathol. R. K. Webster, G. Shaner, and N. K. Van Alfen, eds. Annual Reviews, Palo Alto, CA.

12. Hamilton, R. A., and Ito, P. 1968. "Sunrise solo"- A different colored Solo papaya. Hawaii Agric. Exp. Stn. Circ. No. 69.

13. Jan, F., Pang, S., Tricoli, D., and Gonsalves, D. 2000. Evidence that resistance in squash mosaic comovirus coat protein-transgenic plants is affected by plant developmental stage and enhanced by combination of transgenes from different lines. J. Gen. Virol. 81:2299-2306.

14. Jensen, D. 1949. Papaya diseases with special reference to Papaya ringspot virus. Phytopathology 39:191-211.

15. Kim, M., Moore, P., Zee, F., Fitch, M., Steiger, D., Manshardt, Paull, R., Drew, R., Sekioka, T., and Ming, R. 2002. Genetic diversity of Carica papaya as revealed by AFLP markers. Genome 45:503-512.

16. Lines, R., Persley, D., Dale, J., Drew, R., and Bateson, M. 2002. Genetically engineered immunity to Papaya ringspot virus in Australian papaya cultivars. Mol. Breed. 10:119129.

17. Lius, S., Manshardt, R., Fitch, M., Slightom, J., Sanford, J., and Gonsalves, D. 1997. Patho- gen-derived resistance provides papaya with effective protection against Papaya ringspot virus. Mol. Breed. 3:161-168.

18. Manshardt, R. 1992. Papaya. Pages 489-511 in: Biotechnology of Perennial Fruit Crops. F A. Hammerschlag, and R. E. Litz, eds. CAB International, Wallington, UK.

19. Manshardt, R. M. 1998. 'UHRainbow' papaya Univ. Hawaii, Coll. Trop. Agric. Hum. Resour. Germplasm G-1.

20. Purcifull, D., Edwardson, J., Hiebert, E., and Gonsalves, D. 1984. Papaya ringspot virus. Page 8 in: CMI/AAB Descriptions of Plant Viruses. No. 292. (No. 84 Revised, July 1984).

21. Quemada, H., L'Hostis, B., Gonsalves, D., Reardon, I., Heinrikon, R., Hiebert, E., Sieu, L., and Slightom, J. 1990. The nucleotide sequences of the 3' terminal regions of Papaya ringspot virus strains $\mathrm{W}$ and P. J. Gen. Virol. 71:203-210.

22. Tennant, P. F., Ahmad, M. H., and Gonsalves, D. 2002. Transformation of Carica papaya L. with virus coat protein genes for studies on resistance to Papaya ringspot virus from Jamaica. Trop. Agric. (Trinidad) 79:105-113.

23. Tennant, P., Fermin, G., Fitch, M., Manshardt, R., Slightom, J., Gonsalves, D. 2001. Papaya ringspot virus resistance of transgenic Rainbow and SunUp is affected by gene dosage, plant development, and coat protein homology. Eur. J. Plant Pathol. 107:645-653.

24. Thomas, O. 1993. The current status of papaya production in Jamaica. Pages 1-9 in: Proc. Papaya Mango Seminar, 1993, Kingston, Jamaica.

25. Yeh, S., Jan, F., Chiang, C., Doong, T., Chen, M., Chung, P., and Bau, H. 1992. Complete nucleotide sequence and genetic organization of Papaya ringspot virus RNA. J. Gen. Virol. 73:2531-2541.

26. Yeh, S. D., Bau, H. J., Cheng, Y. H., Yu, T. A., Yang, J. S., and Drew, R. A. 1998. Greenhouse and field evaluations of coat protein transgenic papaya resistant to Papaya ringspot virus. Acta Hortic. 461:321-328.

27. Yeh, S.-D. and Gonsalves, D. 1985. Translation of Papaya ringspot virus RNA in vitro Detection of a possible polyprotein that is processed for capsid, cylindrical-inclusion protein, and amorphous-inclusion protein. Virology 143:260-270. 